\title{
Images of Scientists through the Eyes of the Children
}

\author{
Sibel ÖZSOY ${ }^{1, *}$ \& Berat $\mathrm{AHI}^{2}$ \\ ${ }^{1}$ Aksaray University, Faculty of Education, TURKEY; ${ }^{2}$ Kastamonu \\ University, Faculty of Education, TURKEY \\ Received: 08.03.2013 \\ Accepted: 03.06.2014
}

\begin{abstract}
The purpose of this study is to determine primary school students' images of scientists. As research approach, the survey method, which is frequently used to learn about people's attitudes, beliefs, values, demographics, behavior, opinions, habits, desires, ideas and other types of information, was used. The study was conducted in the spring semester of 2011- 2012 academic year with primary school students enrolling through the first grade to the fifth grade. The data of the study were collected by a Draw-A-Scientist-Test. When scoring a DAST drawing, the raters coded each indicator with either 1 or 0 points depending on the presence or absence of the feature under examination. Drawings revealed that although there are variations from individual to individual, children hold common stereotypical images of scientists. The overwhelming majority of drawings were of male scientists. Children also produced images that represent individuals with messy hair, wearing glasses, wearing a laboratory coat. Also children depicted that scientists usually work in indoors, usually in a laboratory, and perform experiments.
\end{abstract}

Keywords: Science, scientist, image of scientist, draw a scientist test

DOI No: 10.12973/nefmed.2014.8.1.a9

\section{Summary}

\section{Problem Statement}

Drawing pictures is one of the best ways for children to express how they perceive the events, phenomenon, people and objects around them. With the help of the pictures they draw, children can easily organize their thoughts and express the way they perceive the outer world. Children's drawings have been used reliably to determine their perceptions about many

\footnotetext{
* Corresponding Author: Sibel Özsoy, Assoc. Prof. Dr., Aksaray University, Faculty of Education, Department of Elementary School Education, Aksaray, Turkiye.
}

E-mail: sozsoy@aksaray.edu.tr

This study is presented at 5th World Conference on Educational Sciences, Rome, Italy. 
concepts, such as the images of scientists. The study of the images students form about scientists has been the focus of numerous studies through 1950s. The findings of these studies revealed that although there are variations from individual to individual children has a common stereotypic image of a scientist as a male, bald, bespectacled, wearing a laboratory coat, working alone in a laboratory environment, performing dangerous laboratory experiments, and having a limited social life. It is known that children begin to develop their own image of the scientist in early childhood and these images are resistant to change in comparison with other knowledge which they acquired in school. Additionally, the research on children's image of the scientist indicated that images had a significant effect on their attitudes toward science and on their career planning. Thus, although there are many studies reporting children's thoughts about the scientists, studies focusing on determining children's images of scientists should be done regularly to determine the changes in children's views. Bearing these points on mind, the purpose of this study is to determine primary school students' images of scientists.

\section{Methods}

As research approach, the survey method, which is frequently used to learn about people's attitudes, beliefs, values, demographics, behavior, opinions, habits, desires, ideas and other types of information, was used. The study was conducted in the spring semester of 2011-2012 academic year with primary school students enrolling through the first grade to the fifth grade. The data of the study were collected by a Draw-A-Scientist-Test developed by Chambers (1983). When scoring a DAST drawing, the raters coded each indicator with either 1 or 0 points depending on the presence or absence of the feature under examination. Prior to the coding of the drawings, to elucidate potential disagreements researchers discussed the variations in the items that may appear in the drawings.

\section{Findings and Results}

Drawings revealed that although there are variations from individual to individual, children hold common stereotypical images of scientists. The overhelming majority of drawings were of male scientists. Children also produced images that represent individuals as wearing glasses and wearing a laboratory coat. Also children depicted that scientists usually work in indoors, usually in a laboratory, and perform experiments. Findings also showed that the dominant scientist examples in students' minds are male ones such as Einstein, Edison and Newton. 


\section{Conclusions and Recommendations}

From the results of this study, it is concluded that primary school students still depict stereotypic images of scientists. To change children's images, it is recommended to expose them to a variety of experiences, such as field-trips, hands on activities, project based learning, meeting with scientists, of science and scientists. Besides, it is recommended to more emphasize the nature of science within the content of all courses. 


\title{
Çocukların Gözüyle "Bilim İnsanı" Sibel ÖZSOY ${ }^{1,+}$ ve Berat $\mathrm{AHİ}$
}

\author{
${ }^{1}$ Aksaray Üniversitesi, Eğitim Fakültesi, TÜRKİYE; ${ }^{2}$ Kastamonu \\ Üniversitesi, Eğitim Fakültesi, TÜRKİYE
}

\begin{abstract}
Özet - Bu çalışmanın amacı, ilk beş sınıfa devam eden öğrencilerin bilim insanı algısını belirlemektir. Bu araştırmada, var olan durumu en net şekilde ortaya koyabilmek amacıyla tarama modeli kullanılmıştır. Çalışma 2011-2012 eğitim öğretim yllında ilk beş sınıfa devam eden 1174 öğrenci ile yürütülmüştür. Çalışmanın verileri 'Bir Bilim İnsanı Çiz Testi' ile toplanmış, çizimler üzerinde puanlama yapılırken incelenen özelliğin varlığına veya yokluğuna bağlı olarak 1 veya 0 puan ile kodlanmıştır. Çizimlerden elde edilen sonuçlar, öğrencilerin sahip olduğu bilim insanı imajlarında ortak noktaların olduğunu göstermiştir. Öğrencilerin büyük bir çoğunluğu resimlerinde erkek bilim insanına yer verirken, bilim insanının fiziksel özelliklerini dağınık saçlı, gözlüklü ve laboratuar önlüğü giyen bireyler olarak tanımlamışlardır. Çalışmadan elde edilen sonuçlar ayrıca öğrencilerin çizimlerinde bilim insanlarının genelde iç mekânlarda, çoğunlukla laboratuarda çalıştığını ve deney yaptıklarını vurguladıklarını göstermiştir.
\end{abstract}

Anahtar Kelimeler: Bilim, bilim insanı, bilim insanı algısı, bir bilim insanı çiz testi

DOI No: 10.12973/nefmed.2014.8.1.a9

\section{Giriş}

Bilginin katlanarak arttı̆̆ı, teknolojinin büyük bir hızla ilerlediği çağımızda, yaşanan bu hızlı değişime ayak uydurabilen, bilgiye ulaşabilen, teknolojiyi kullanabilen, karşılaştığı yeni bir bilgiyi anlayan, yorumlayan, bilgi üreten, karşılaştığı sorunları çözen, bilimsel süreç becerilerine sahip, bilimsel çalışmalara ve sonuçlarına değer veren, bilim ve teknoloji okuryazarı bireyler yetiştirebilmek her ülkenin öncelikleri arasında yer almaktadır. Bu durum, çocuklarımızın bilgi çağı insanı olacak şekilde yetiştirilmelerini zorunlu kılmaktadır. Gelişmiş ülkeler, hızla artan bilgiyi ve onunla paralel gelişen teknolojiyi doğru anlayan ve kullanan,

\footnotetext{
${ }^{\dagger}$ İletişim: Sibel Özsoy, Doç. Dr., Aksaray Üniversitesi, Eğitim Fakültesi, İlköğretim Bölümü, Aksaray, Türkiye.

E-posta: sozsoy@aksaray.edu.tr
}

Not: Bu çalışma Roma'da düzenlenen '5. World Conference on Education'da sunulmuştur. 
çağın gerektirdiği bilgi, beceri ve anlayışlara sahip, bir bilim insanının bakış açısıyla olayları değerlendiren bireyleri yani bilgi çağı insanını yetiştirebilmek adına öğretim programlarında değişiklikler yapmaktadırlar. Ülkemizde de bu ihtiyaçtan yola çıkarak, 2005 yılında başlayan bir reform hareketi ile kademeli olarak ilköğretim ve ortaöğretim öğretim programları güncellenmiştir. Değiştirilen programlarda öğretimde yapılandırıcı öğrenme yaklaşımı temel alınmış, öğrenme pasif bir süreç olarak değil, öğrencinin öğrenme sürecine katılımını gerektiren, aktif, sürekli ve gelişimsel bir süreç olarak tanımlanmıştır. Öğretim programlarında, yapılandırıcı öğrenme yaklaşımının yanı sıra, keşfetme, işbirliğine dayalı öğrenme, probleme dayalı öğrenme gibi diğer öğrenci merkezli stratejiler de benimsenmiş, bu stratejilerle birlikte öğrencilere bilimsel süreç becerilerinin kazandırılması amaçlanmıştır. Böylelikle, öğretmen tarafından aktarılan bilgileri ezberleyen, aynen kabul eden ve yönlendirilmeyi bekleyen öğrenciler yerine, karşılaştıkları bilgiyi yorumlayarak anlamlandıran ve yeni bilgiler üreten öğrenciler yetiştirilmesi hedeflenmiştir. Ancak böyle bir durumda, bilgi üreten, sorun çözen ve bilimsel düşünen, yaptığı çalışmalarda bir bilim insanı edasıyla bilimsel yöntemin basamaklarını uygulayabilen, yaptığı çalışmaları bilimsel temellere dayandırabilen, bir bilim insanının özelliklerine sahip, yaratıcı bireyler yetiştirmek mümkün olacaktır.

İlkokul kademesine devam eden çocuklar, çevrelerinde meydana gelen olaylara karşı ilgili, bu olayların nedenleri ve sonuçları hakkında oldukça meraklıdır. Öğrencilerin bilim ve bilim insanına yönelik algıları büyük ölçüde bu yaşlarda şekillenmekte, bu kademede edindikleri deneyimlerle birlikte zihinlerinde oluşturdukları bilim insanı imajı gelecekte bilimsel çalışmalara devam edip edemeyeceklerini (Finson, 2002, Hammrich, 1997; Schibeci, 1986) ve günlük hayatlarında karşılaştıkları bir problemi bilimsel süreç becerilerinden faydalanarak çözüp çözemeyeceklerini büyük ölçüde etkilemektedir. Bireyin amaçlı ve planlı bilgilerle ilk kez karşılaştı̆gı ilkokul yıllarında, öğrencinin doğal dünyayı daha anlamlı bir şekilde yorumlaması, neden-sonuç ilişkileriyle muhakeme yeteneğinin gelişmesi, bilimi ve bilim insanlarını sevme ve örnek alma yönünde olumlu tutumlar geliştirmesi açısından büyük önem taşımaktadır. Bu nedenle de bu dönemde bilime ve bilim insanına karşı olumlu tutum geliştirilmesinin sağlanması, bilgi çağına ayak uydurabilen bireylerin yetiştirilebilmesi için çok önemli bir dönüm noktasıdır. 
Araştırmacılar, farklı yaşlarda olan, farklı sınıf düzeylerinde öğrenimlerine devam eden öğrencilerin bilime ve bilim insanına yönelik algılarını belirlemeye yönelik birçok araştırma yapmışlardır (Barman, 1997; Chambers, 1983; Finson, 2002; Hammrich, 1997; Kaya, Dogan \& Ocal, 2008; Mead \& Metraux, 1957; Newton \& Newton, 1992; Schibeci, 1986; Song \& Kim, 1999). Öğrencilerin bilim ve bilim insanlarına yönelik algıları ilk kez lise öğrencileri düzeyinde Mead ve Metraux (1957) tarafindan incelenmiştir. $\mathrm{Bu}$ araştırma sonucunda öğrenciler, bilim insanını; beyaz önlük giyen, laboratuarda çalışan, çoğunlukla erkek, orta yaşl1, gözlük takan, dağınık saçlı, kamburu çıkmış ve yorgun olarak tanımlamışlardır. Böyle bir düşünce, öğrencilerin bilimi ve bilimin öznesi konumundaki bilim insanını doğru anlamlandırmalarına, bilimsel alanlarda kariyer yapmalarına, bilimsel bilgileri ve bilimsel süreç becerilerini günlük hayatlarında kullanmalarına engel teşkil edecek niteliktedir. Yine aynı çalışmada öğrenciler; bilim insanının laboratuarda çalıştığını, etrafının deney tüpleri, bünzen ocakları, beherler, cam balonlar ve şişeler gibi laboratuar malzemeleri ile çevrili olduğunu belirtmişlerdir. Mead ve Metraux'in (1957) yapmış olduğu bu çalışmadan sonra ilkokul ve ortaokul öğrencilerinin bilim insanı algılarını belirlemeye yönelik yapılan araştırmaların sonuçları, öğrencilerin bilim insanının özelliklerine yönelik genellikle kalıplaşmış düşüncelere sahip olduğunu göstermektedir.

Gounsoulin (2001) yedinci ve sekizinci sınıfa devam eden 353 öğrencinin katılımı ile öğrencilerin bilim ve bilim insanı imajlarını ve 1rk, cinsiyet ve sosyoekonomik düzeyin bu imajlara olan etkisini belirlemek adına bir çalışma yürütmüştür. Bu çalışmanın sonuçları diğer araştırmalardan elde edilen sonuçlarla benzerlik gösteren nitelikte olup öğrencilerin bilim insanını "erkek, laboratuar önlüğü giymiş ve gözlüklü” olarak tanımladıklarını ortaya koymuştur. Çalışmadan elde edilen bir diğer bulgu da bilim insanının cinsiyetine yöneliktir. Çalışmada yer alan erkek öğrenciler bilim insanını erkek olarak çizerken, kız öğrencilerin çizimlerinde hem erkek hem kadın bilim insanına yer verdikleri görülmüştür.

Ülkemizde yapılan araştırmalarda da benzer sonuçlar elde edilmiştir. Nuhoğlu ve Afacan (2007) tarafından ilköğretime devam eden öğrencilerle yapılan araştırmanın sonuçları, çalışmaya katılan öğrencilerin \%60'ının bilim insanını erkek, \%23'ünün ise kadın olarak tanımladığını göstermektedir. Bir başka çalışmada Buldu (2006) sosyoekonomik düzey ve cinsiyet faktörü açısından, 5 ile 8 yaş arası öğrencilerin bilim insanı çizimlerinden faydalanarak bilim insanı algılarını belirlemiştir. Çalışmada erkek çocukların, çizimlerinde hiç kadın bilim insanı çizmedikleri, kız çocuklarının ise kadın bilim insanına çizimlerinde yer 
verdikleri görülmüştür. Ayrıca, yine aynı çalışmada öğrencilerin yaşları büyüdükçe daha detaylı çizimler yaptıkları bulunmuştur. Sosyoekonomik düzeye göre yapılan değerlendirmede ise düşük sosyoekonomik düzeye sahip olan öğrencilerin yüksek olanlara göre daha tipik çizimler yaparak detaya yer vermedikleri gözlenmiştir. Güler ve Akman'ın (2006) yapmış olduğu araştırmada laboratuar önlüğü, gözlük, sakal ve dağınık saç, laboratuar araç gereçleri öğrencilerin çizimlerinde en sık rastlanan öğeler olarak nitelendirilmiştir. Kaya, Doğan ve Öcal (2008) araştırmalarında, çalışmalarına katılan öğrencilerin bilim insanını laboratuar önlüklü, gözlüklü, erkek ve mutlu bir yüz ifadesi ile genelde laboratuarda çalışan bir kişi olarak nitelendirdiklerini ortaya koymuştur.

Öğrencilerin bilime ve bilim insanına yönelik tutum ve değerlerini, bilim insanına yönelik görüşlerini belirlemek amacıyla yapılan araştırmalarda (Mead \& Metraux, 1957; Beardslee \& O’Dowd, 1961; Rodriguez, 1975; Gardner, 1975) birçok farklı ölçek kullanılmıştır. $\mathrm{Bu}$ alandaki en temel araştırmalardan biri olan Mead ve Metraux tarafindan 1957 yılında yapılan çalışmada, araştırmacılar, 35000 lise öğrencisinin bilim ve bilim insanı hakkındaki düşüncelerini belirlemek amacıyla açık uçlu sorular kullanmışlardır. Krajkovich, 1978 yılında yapmış olduğu çalışmada, öğrencilerin sahip olduğu bilim ve bilim insanı imgelerini karşılaştırabilmek adına yeni bir ölçeğin geliştirilmesinin gerektiğini ortaya koymuştur. Mead ve Metraux tarafindan 1982 yılında 25 olumlu, 25 olumsuz durumdan oluşan 'Bilim ve Bilim İnsanı İmge Ölçeği' geliştirilmiştir. Öğrencilere ölçekte verilen durumlara katılıp katılmadıkları sorulmuş, öğrencilerin verdikleri yanıtlar kategorilere ayrılarak değerlendirilmiştir. Araştırmacılar tarafından geliştirilen ölçeklerin birçoğuna öğrencilerin yazarak cevap vermesi gerektiğinden, bu durum uygulamada bazı problemleri beraberinde getirmiştir. Chambers, 1983 yılında yaptığı araştırmasında öğrencilerin bilim insanına yönelik düşüncelerini çizerek ifade edebilmelerini sağlamak amacıyla 'Bir Bilim İnsanı Çiz Testi'ni (Draw A Scientist, DAST) geliştirmiştir. Çizimler, çocukların farklı konulardaki algılarını belirlemek üzere kullanılabilecek geçerli ve güvenilir araçlardır (Medina-Jerez, Middleton \& Orihuela-Rabaza, 2011; Özsoy, 2012; Özsoy, 2012a; Picker \& Belly, 2000; Renoe, 2003; Villanen \& Jonsson, 2013). Çizimlerin zenginliği aynı zamanda çocukların kendi dünyaları ve duygularına ilişkin bilgi sağlamaktadır. İmajlar, bireylerin dünyayı nasıl gördüğünü yansıttığından (Knight \& Cunningham, 2004), araştırmacılara bireyler hakkında önemli bilgi sağlamaktadır. Chambers (1983) tarafından geliştirilen 'Bir Bilim Adamı Çiz Testi’ geliştirildiği günden beri farklı toplumlarda, farklı kültürlerde 
güvenilir sonuçlar sağlayan bir ölçek olarak karşımıza çıkmaktadır. Bu testte öğrenciler basit olarak bilim insanıyla ilgili fikirlerini boş bir sayfaya çizmektedirler ve bu çizimler daha sonra çizimlerde yer alan ve almayan karakterlere göre değerlendirilmektedirler. Ayrıca Bir Bilim Adamı Çiz Testinin uygulama süresinin kısa olması özellikle ilkokul dönemindeki öğrencilerin yaş grubunun dikkat süresi ile de uyuşmaktadır. Bir Bilim İnsanı Çiz Testi geliştirildiği günden bu yana onlarca çalışmada kullanılan, günümüzde de hâlâ değerini koruyan etkili bir ölçek olma özelliğini sürdürmektedir.

\section{Araştırmanın Amacı ve Önemi}

Yeni neslin, bilimi ve bilim insanını anlayan bireyler olarak yetiştirilmesi amaçlanıyorsa öncelikle onların bilim ve bilim insanı hakkındaki görüşleri belirlenmelidir (Schibeci, 2006). Öğrencilerin bilim insanı imajları yaklaşık 80 yıldır çalışılan bir konu olarak karşımıza çıkmasına ve bu alanda oldukça yoğun bir bilgi birikimi olmasına rağmen, ilköğretime devam eden öğrencilerin bilim insanı algılarını ele alınan çalışmaların azlığı dikkat çekicidir. Öğretim programlarında farklı ders ve sınıf seviyelerinde ele alınan bilim, bilimsel çalışma ve bilim insanına ait kazanım ve becerilerin etkili bir şekilde öğrencilere kazandırılabilmesi için öğrencilerin bilim insanı imajlarının ortaya konmasına ihtiyaç vardır. Öğrencilerin bilime ve bilim insanına yönelik imajlarının betimlenmesi; öğretmenlere ve eğitim politikacılarına okullarda verilen eğitime dair faydalı bilgiler sağlayacaktır. Bu yüzden bu konuyla ilgili araştırmaların farklı değişkenlerle ve farklı çalışma grupları ile devamına ihtiyaç duyulmaktadır. Bu kapsamda, bu çalışmanın amacı, ilk beş sınıfa devam eden öğrencilerin bilim insanı imajlarını belirlemektir.

\section{Yöntem}

\section{Araştırmanın Modeli ve Çalışma Grubu}

$\mathrm{Bu}$ araştırmada, var olan durumu en net şekilde ortaya koyabilmek amaciyla tarama modeli kullanılmıştır. Öğrencilerin bilim insanı çizimlerinden elde edilen kodlar frekans ve yüzde olarak raporlanmıştır. Çalışmaya katılan toplam 1174 öğrencinin sınıf düzeylerine ve cinsiyetlerine göre dağılımı Tablo 1'de verilmiştir.

Tablo 1. Öğrencilerin sınıf düzeylerine ve cinsiyetlerine göre dağılımı

\begin{tabular}{cccc}
\hline & Klz & Erkek & Toplam \\
\hline 1. Sinif & 72 & 54 & 126 \\
\hline 2. Sinıf & 72 & 80 & 152 \\
\hline 3. Sinif & 66 & 74 & 140 \\
\hline
\end{tabular}




\begin{tabular}{cccc}
\hline 4. Sinif & 216 & 150 & 366 \\
\hline 5. Sinif & 204 & 186 & 390 \\
\hline Toplam & 630 & 544 & 1174 \\
\hline
\end{tabular}

\section{Verilerin Toplanması}

$\mathrm{Bu}$ araştırmanın verileri 2011-2012 bahar döneminde toplanmıştır. Çalışma grubunu oluşturan öğrencilerin, sınıf düzeyleri göz önüne alındığında, bilim insanı hakkındaki görüşlerini belirleyebilmek amacıyla, Chambers (1983) tarafindan geliştirilen 'Bir Bilim İnsanı Çiz Testi’ kullanılmıştır. Bir Bilim İnsanı Çiz Testi, çalışma grubundaki öğrencilere, araştırmacılar tarafından örneklemdeki okullara gidilerek uygulanmıştır. Uygulama sırasında öğrencilere çizimlerini yapabilecekleri resim kâğıtları ve boya kalemleri dağıtılmış, öğrenciler, kâğıda, bilim insanı resmi çizmeleri istenmiştir. Öğrencilerden kişisel bilgilerini resim yaptıkları kâğıtların arkasına not etmeleri istenmiş, elde edilen verilerin gizliliğini sağlamak için sadece cinsiyet ve sınıf düzeyine ait bilgileri yazmaları istenmiştir. Uygulama, bir ders saatinde tamamlanmış, öğrencilerin çalışmaya katılımının gönüllülüğü sağlanmış, bu çalışmalarının ders notlarında herhangi bir etkisinin olmayacağı söylenmiştir. Verilerin toplanması sırasında araştırmacılar uygulama yaptıkları sınıflarda hazır bulunmuş, öğrencilerin çizimlerinde anlaşılması güç bazı öğeleri öğrencilere sorarak not almışlardır.

\section{Verilerin Analizi}

Veri toplama araciyla elde edilen verilerin analizi SPSS 13 for Windows paket programı kullanılarak gerçekleştirilmiştir. Elde edilen 1174 çizim, araştırmacılar tarafından öğelerin varlığı ve yokluğu göz önünde bulundurularak kodlanmıştır. Elde edilen bu kodlar çalışmanın bulgularını oluşturmuştur. Kodlama öncesinde araştırmacılar, meydana gelebilecek potansiyel anlaşmazlıkları azaltmak amacı ile bir araya gelerek, resimlerden elde edilecek kodlar ve özellikleri üzerinde konuşmuşlardır. Elde edilen veriler yüzde (\%) ve frekans $(f)$ analizi ile raporlanmıştır.

\section{Bulgular}

Bilim İnsanının Fiziksel Özellikleri

Necatibey Eğitim Fakültesi Elektronik Fen ve Matematik Eğitimi Dergisi

Necatibey Faculty of Education, Electronic Journal of Science and Mathematics Education 
Öğrencilerin, bilim insanı çizimlerinde yer verdikleri fiziksel özelliklerin dağılımları Tablo 2'de cinsiyet ve sınıf düzeylerine göre verilmektedir. Yapılan araştırmalarda öğrencilerin bilim insanını beyaz, önlük giyen, saçları beyazlamış, dökülmüş ya da dağınık, gözlüklü, orta yaşlı genellikle erkek olarak tanımladıkları ortaya çıkmıştır. Belirtilen özelliklerden birçoğu bu araştırmaya katılan öğrenciler tarafından da kullanılmıştır. Çalışmaya katılan öğrencilerin \%4.6'sı bilim insanını yaşlı, \%19.9’u gözlüklü, \%16.5’i önlüklü, \%11.9'u dağınık saçlı, \%3.7'si kel, \%4.8'i ise sakallı veya bıyıklı çizmişlerdir. Bu özelliklerin yanı sıra \%40.4'ü bilim insanlarını mutlu çizerken, \%3.2'si mutsuz çizmişlerdir. Sınıf düzeyi arttıkça bilim insanını önlüklü çizen öğrencilerin sayıca artması, mutlu çizen öğrencilerin ise sayıca azalması dikkat çekmektedir. Bilim insanının fiziksel özelliklerini yansıtan örnekler Şekil 1'de verilmiştir.

Tablo 2. Bilim insanı çizimlerinde elde edilen fiziksel özelliklerin sınıflara göre frekans ve yüzde dağılımları

\begin{tabular}{|c|c|c|c|c|c|c|c|}
\hline & & 1. sinif & 2. sinif & 3. sinif & 4. sinif & 5. sinif & Toplam \\
\hline \multirow[t]{2}{*}{ Genç } & $f$ & 0 & 0 & 46 & 72 & 52 & 270 \\
\hline & $\%$ & 0 & 0 & 32.9 & 19.7 & 13.3 & 22.9 \\
\hline \multirow[t]{2}{*}{ Yaşlı } & $f$ & 0 & 0 & 4 & 38 & 12 & 54 \\
\hline & $\%$ & 0 & 0 & 2.9 & 10.4 & 3.1 & 4.6 \\
\hline \multirow[t]{2}{*}{ Gözlüklü } & $f$ & 0 & 0 & 32 & 110 & 92 & 234 \\
\hline & $\%$ & 0 & 0 & 22.9 & 30.1 & 23.6 & 19.9 \\
\hline \multirow[t]{2}{*}{ Önlüklü } & $f$ & 6 & 4 & 22 & 74 & 88 & 194 \\
\hline & $\%$ & 4.8 & 2.6 & 15.7 & 20.2 & 22.6 & 16.5 \\
\hline \multirow[t]{2}{*}{ Mutlu } & $\mathrm{f}$ & 58 & 116 & 80 & 110 & 110 & 474 \\
\hline & $\%$ & 46.0 & 76.3 & 57.1 & 30.1 & 28.2 & 40.4 \\
\hline \multirow[t]{2}{*}{ Mutsuz } & $\mathrm{f}$ & 2 & 0 & 0 & 16 & 20 & 38 \\
\hline & $\%$ & 1.6 & 0 & 0 & 4.4 & 5.1 & 3.2 \\
\hline \multirow[t]{2}{*}{ Dağınık saçlı } & $f$ & 0 & 0 & 6 & 70 & 64 & 140 \\
\hline & $\%$ & 0 & 0 & 4.3 & 19.1 & 16.4 & 11.9 \\
\hline \multirow[t]{2}{*}{ Kel } & $f$ & 0 & 0 & 10 & 24 & 10 & 44 \\
\hline & $\%$ & 0 & 0 & 7.1 & 6.6 & 2.6 & 3.7 \\
\hline \multirow[t]{2}{*}{ Sakallı/Bıyıklı } & $\mathrm{f}$ & 0 & 0 & 2 & 28 & 26 & 56 \\
\hline & $\%$ & 0 & 0 & 1.4 & 7.7 & 6.7 & 4.8 \\
\hline
\end{tabular}



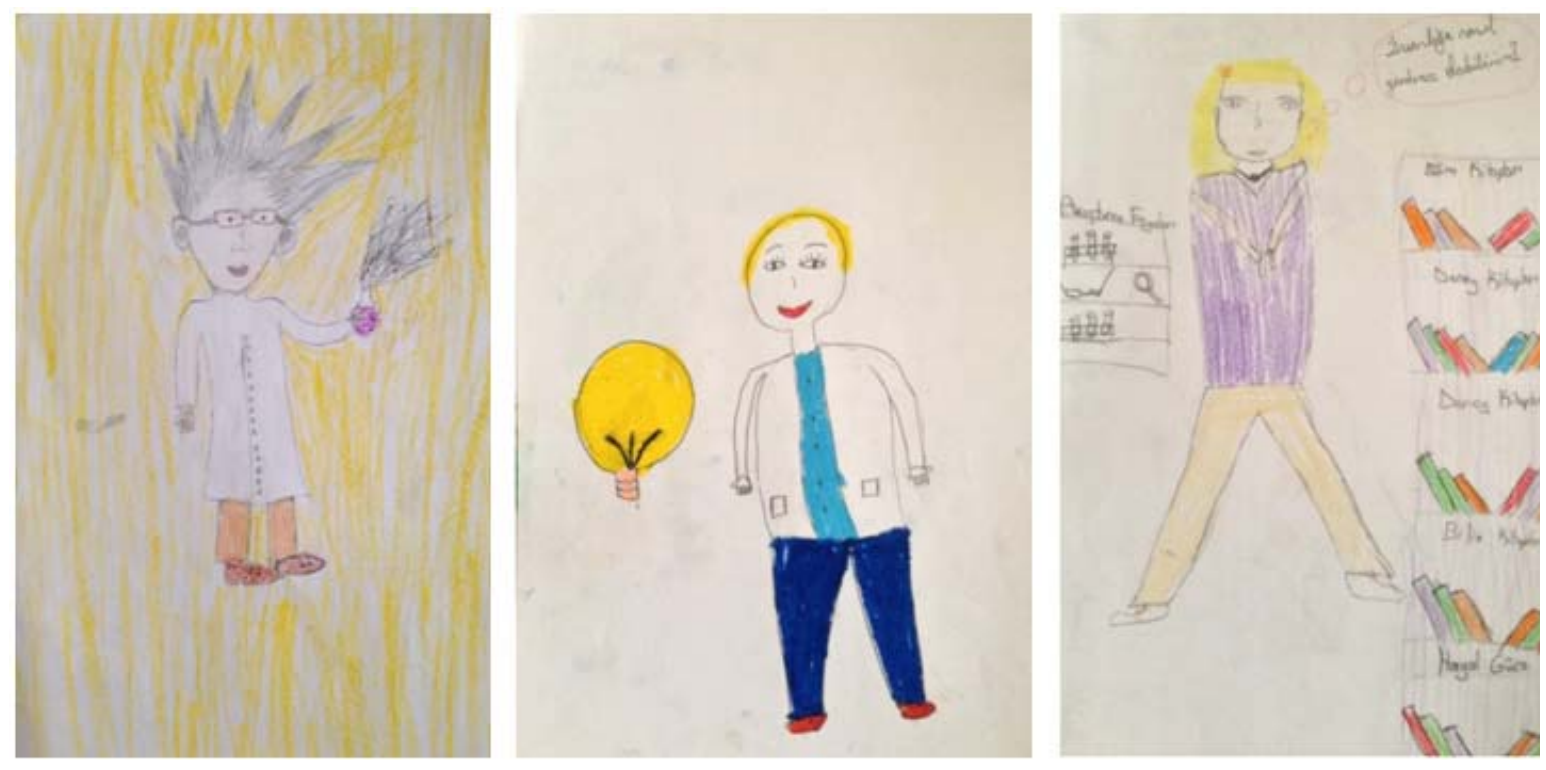

Şekil 1. Bilim İnsanının Fiziksel Özellikleri

Bilim Insanının Cinsiyeti

Çalışmaya katılan öğrencilerden 770’i (\%65.6) çizimlerinde bilim insanını erkek olarak resmederken, 264'ü (\%22.5) bilim insanını kadın olarak resmetmiştir. Öğrencilerin 130’u (\%11) çizimlerinde insan figürü kullanmazken, sadece 10 'u $(\% 0,9)$ erkek ve kadın bilim insanlarını beraber çalışırken göstermişlerdir. Çalışmadan elde edilen bir diğer sonuçta kadın bilim insanı içeren çizimlerin sadece 16'sının erkek öğrenciler tarafından yapılmış olmasıdır. Geri kalan 248 çizim, kız öğrenciler tarafından yapılmıştır. Çalışmaya katılan öğrencilerden sadece 10’u (\%2.6'sı) kadın ve erkek bilim insanlarını aynı çizimde birlikte çalışırken çizmişlerdir. Kadın ve erkek bilim insanını bir arada çizen öğrencilerin tamamının beşinci sınıfa devam ediyor olması çalışmadan elde edilen bir başka bulgudur. Öğrencilerin cinsiyetlerine göre çizimlerindeki bilim insanlarının cinsiyetlerine göre dağılımı Tablo 3'te belirtilmiştir. 
Tablo 3. Öğrencilerin cinsiyetlerine göre çizimlerdeki bilim insanlarının cinsiyetlerine göre

\begin{tabular}{lcccc} 
& \multicolumn{5}{c}{ dağ 1 lım } \\
& & Kız öğrenciler & Erkek öğrenciler & Toplam \\
\hline Kadın & $\mathrm{f}$ & 248 & 16 & 264 \\
\cline { 2 - 5 } & $\%$ & 39,4 & 2.9 & 22,5 \\
\hline Erkek & $\mathrm{f}$ & 312 & 458 & 770 \\
\cline { 2 - 5 } & $\%$ & 49.5 & 84.2 & 65.6 \\
\hline Kadın ve Erkek bir arada & $\mathrm{f}$ & 0 & 10 & .9 \\
\cline { 2 - 5 } & $\%$ & 0 & 1.8 & 130 \\
\hline İnsan figürü yok & $\mathrm{f}$ & 70 & 11 & 11.1 \\
\cline { 2 - 5 } & $\%$ & 11.1 & & \\
\hline
\end{tabular}

Öğrencilerin çizimlerinde yansıttıkları bir bilim insanının cinsiyetine yönelik çizimleri sınıf düzeylerine göre karşılaştırıldığında ise tüm sınıf düzeylerinde öğrencilerin ağırlıklı olarak bilim insanını erkek olarak resmettikleri gözlenmektedir. Tüm sınıf düzeyleri değerlendirildiğinde kadın bilim insanı çizimlerinde düzeye göre bir azalma ya da artma gözlenmemekte, en çok ikinci sınıf öğrencilerinin (\%39.9) kadın bilim insanı çizdikleri görülmektedir. Sınıf düzeylerine göre çizimlerdeki bilim insanlarının cinsiyetlerine göre dağılımı Tablo 4'te bilim insanının cinsiyeti alt başlığından elde edilen verilere örnek teşkil edecek resimler Şekil 2'de gösterilmektedir.

Tablo 4. Sınıf düzeylerine göre çizimlerdeki bilim insanlarının cinsiyetlerine göre dağ̊lımı

\begin{tabular}{|c|c|c|c|c|c|c|c|}
\hline & & 1. sinif & 2. sinif & 3. sinif & 4. sinif & 5. sinif & Toplam \\
\hline \multirow[t]{2}{*}{ Kadın } & $f$ & 36 & 61 & 40 & 57 & 70 & 264 \\
\hline & $\%$ & 28.6 & 39.9 & 28,6 & 15.6 & 17.9 & 22.5 \\
\hline \multirow[t]{2}{*}{ Erkek } & $f$ & 70 & 88 & 72 & 256 & 284 & 770 \\
\hline & $\%$ & 55.6 & 57.5 & 51.4 & 69.9 & 72.8 & 65.6 \\
\hline \multirow[t]{2}{*}{ Kadın ve Erkek bir arada } & $\mathrm{f}$ & 0 & 0 & 0 & 0 & 10 & 10 \\
\hline & $\%$ & 0 & 0 & 0 & 0 & 2.6 & .9 \\
\hline \multirow[t]{2}{*}{ İnsan figürü yok } & $\mathrm{f}$ & 20 & 4 & 28 & 52 & 26 & 130 \\
\hline & $\%$ & 15.8 & 2.6 & 20 & 14.3 & 6.7 & 11.1 \\
\hline
\end{tabular}



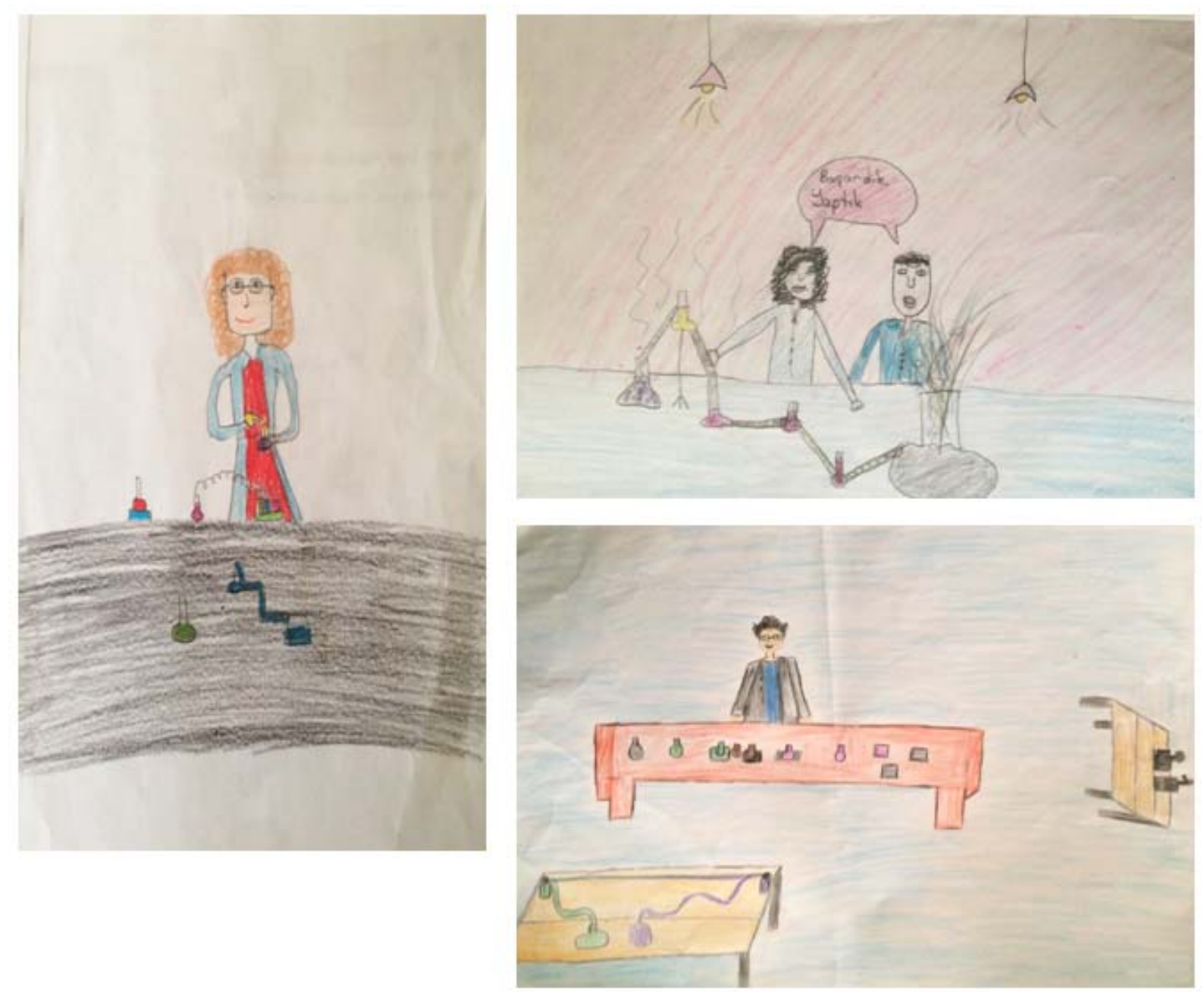

Şekil 2. Bilim İnsanının Cinsiyeti

\section{Bilim Ínsanının Çalışma Alanı}

Öğrencilerin çizimlerindeki bilim insanının çalışma alanlarına yönelik frekans ve yüzdelerin öğrencilerin cinsiyetlerine ve sınıf düzeylerine göre dağılımı Tablo 5'de verilmiştir. Çizimler incelendiğinde kız ve erkek öğrencilerin de bilim insanının çalışma ortamı olarak en fazla laboratuar resmi çizdikleri görülmektedir. Kız öğrencilerin \%55.3’ü, erkek öğrencilerin ise \%44.8'i bilim insanlarını laboratuarda çalışırken göstermişlerdir. Sınıf düzeyi temel alındığında yapılan değerlendirmede de benzer bir sonuç ortaya çıkmaktadır. Çalışmaya katılan öğrencilerin \%50.9'u çizimlerinde bilim insanını laboratuar ortamında göstermişlerdir. Çizimlerde laboratuar dışında iki çalışma alanı daha ön plana çıkmaktadır. Çalışmaya katılan öğrencilerden 32 tanesi (\%2.7'si) bilim insanını doğada, 24 tanesi ise (\%2.1'i) uzayda çizmişlerdir. Şekil 1'de bilim insanını doğada ve uzayda resmeden iki çizim 
yer almaktadır. Uzay çiziminde kadın bilim insanı ile birlikte gezegenler, güneş ve yıldızlar resmedilirken, doğa çiziminde uğur böceğini belki de resimde yer alan kelebek ve bitkiyi inceleyen, elinde büyüteç tutan kadın bir bilim insanı resmedilmiştir. Otuz iki doğa çiziminden 16 tanesinin birinci sınıf öğrencileri tarafından yapılmış olması, 24 uzay çiziminden 12 tanesinin ikinci sınıf öğrencileri tarafından yapılmış olması çalışmadan elde edilen dikkat çekici sonuçlar arasında yer almaktadır. Geriye kalan 520 öğrenci ise (\%44.3'ü) bilim insanını herhangi bir ortam içerisinde resmetmemişlerdir. Laboratuar ortamı çizimlerine cam eşyalar, kitaplar, masa eşlik ederken, doğa çizimlerine büyüteç, uzay çizimlerine ise uzay mekiği, astronot kıyafetleri eşlik etmektedir.

Tablo 5. Bilim insanı çizimlerinde elde edilen bilim insanının çalışma alanlarının cinsiyet ve sınıflara göre frekans ve yüzde dağılımları

\begin{tabular}{|c|c|c|c|c|c|c|c|c|c|}
\hline & & $\mathrm{K}_{1 \mathrm{Z}}$ & Erkek & 1. sinif & 2. sinif & 3. sinif & 4. sinif & 5. sinif & Toplam \\
\hline \multirow{2}{*}{ Laboratuar } & $f$ & 354 & 244 & 52 & 84 & 88 & 196 & 178 & 598 \\
\hline & $\%$ & 55.3 & 44.8 & 41.3 & 55.3 & 62.9 & 53.6 & 45.7 & 50,9 \\
\hline \multirow{2}{*}{ Doğa } & $f$ & 12 & 20 & 16 & 4 & 6 & 2 & 4 & 32 \\
\hline & $\%$ & 1,9 & 3.7 & 12.7 & 2.6 & 4.3 & 0,5 & 1,0 & 2.72 \\
\hline \multirow{2}{*}{ Uzay } & $f$ & 14 & 10 & 4 & 12 & 0 & 0 & 8 & 24 \\
\hline & $\%$ & 2,2 & 1.8 & 3.2 & 7.9 & 0 & 0 & 2,1 & 2,1 \\
\hline
\end{tabular}
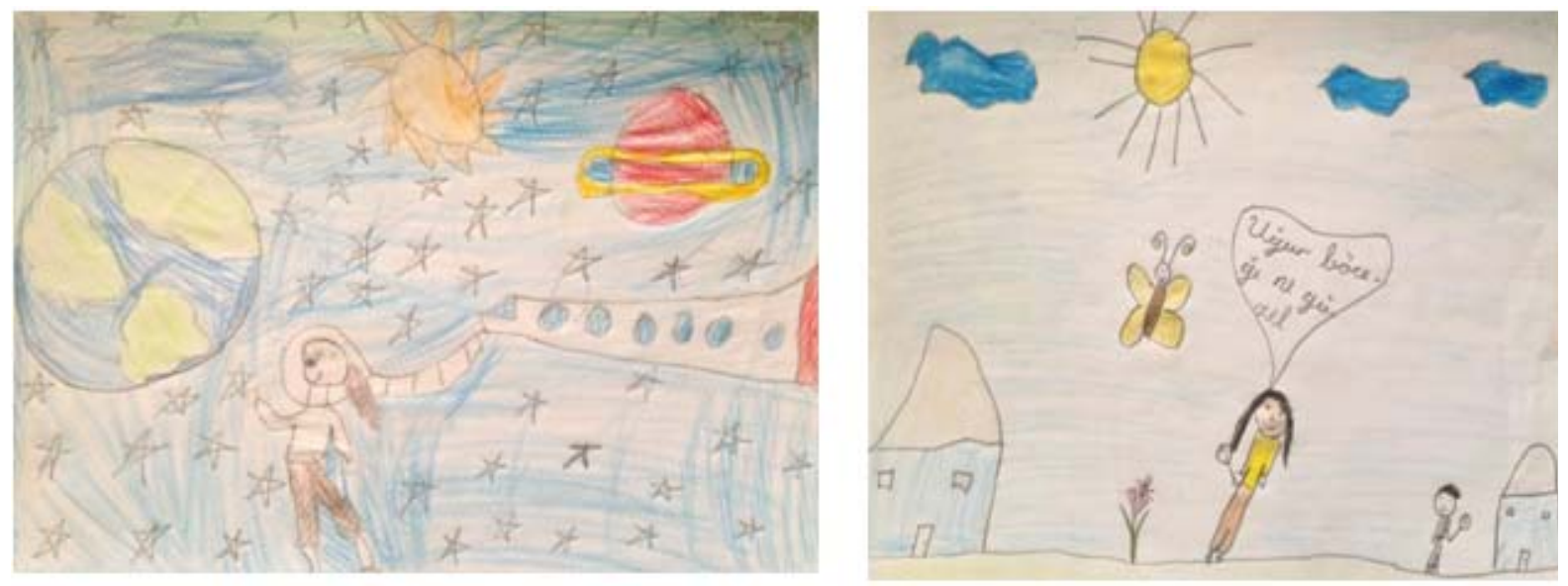

Şekil 3. Uzayda ve Doğada Bilim İnsanı

\section{Bilimsel Araçlar ve Bilgi Sembolleri}

Öğrencilerin çizimlerinde yer alan bilimsel araçlar, bilim insanının çalışma alanına göre değişiklik göstermekle beraber en sık kullanılan bilimsel araçlar arasında deney tüpü ve beher gibi cam eşyalar, mikroskop, teleskop, büyüteç yer almaktadır. Öğrencilerin çizimlerinde yer 
alan bilimsel araçların frekans ve yüzdelerinin öğrencilerin sınıf düzeylerine göre dağılımı Tablo 6'da, kullanılan bilimsel araçları ve bilgi sembollerini gösteren bir resim Şekil 4'te verilmiştir. Bu bilimsel araçların yanı sıra çizimlerde bilgi sembollerinin kullanımı da dikkat çekmektedir. Çalışmaya katılan öğrencilerin \%19.08'i çizimlerinde kitaba yer vermiştir. Ayrıca, öğrencilerin \%59.62'si bilim insanı çizimlerinde masaya yer vermişlerdir. Resimlerde nadiren posterlere ve matematiksel işlemlere yer verildiği görülmektedir. Resimlerdeki teknoloji kullanımının azlığı da dikkat çekmektedir. Bilgisayar, çizimlerde kullanılan teknolojik araçlardan biri olmasına rağmen öğrencilerin sadece \%1.02'si çizimlerinde bilgisayara yer vermiştir.

Tablo 5. Bilim insanı çizimlerinde elde edilen bilimsel araçların ve bilgi sembollerinin sınıflara göre

\begin{tabular}{|c|c|c|c|c|c|c|c|}
\hline & & 1. sinif & 2. sinif & 3. sinif & 4. sinif & 5. sinif & Toplam \\
\hline \multirow{2}{*}{ Cam Malzeme } & $\mathrm{f}$ & 52 & 84 & 88 & 374 & 178 & 772 \\
\hline & $\%$ & 41.3 & 55.3 & 62.9 & 49.5 & 45.6 & 66.09 \\
\hline \multirow{2}{*}{ Mikroskop } & $\mathrm{f}$ & 6 & 0 & 0 & 12 & 8 & 26 \\
\hline & $\%$ & 4.8 & 0 & 0 & 1.6 & 2.1 & 2.21 \\
\hline \multirow{2}{*}{ Teleskop } & $\mathrm{f}$ & 2 & 0 & 6 & 28 & 20 & 56 \\
\hline & $\%$ & 1.6 & 0 & 4.3 & 3.7 & 5.1 & 4.77 \\
\hline \multirow{2}{*}{ Büyüteç } & $\mathrm{f}$ & 2 & 0 & 0 & 6 & 6 & 14 \\
\hline & $\%$ & 1.6 & 0 & 0 & 0.8 & 1.5 & 1.19 \\
\hline \multirow{2}{*}{ Masa } & $\mathrm{f}$ & 46 & 80 & 90 & 322 & 162 & 700 \\
\hline & $\%$ & 36.5 & 52.6 & 64.3 & 42.6 & 41.5 & 59.62 \\
\hline \multirow{2}{*}{ Kitap } & $\mathrm{f}$ & 0 & 16 & 50 & 100 & 58 & 224 \\
\hline & $\%$ & 0 & 10.5 & 35.7 & 13.2 & 14.9 & 19.08 \\
\hline \multirow{2}{*}{ Bilgisayar } & $\mathrm{f}$ & 0 & 0 & 0 & 8 & 4 & 12 \\
\hline & $\%$ & 0 & 0 & 0 & 1.1 & 1.0 & 1.02 \\
\hline \multirow{2}{*}{ Uzay mekik } & $\mathrm{f}$ & 2 & 4 & 10 & 8 & 2 & 26 \\
\hline & $\%$ & 1.6 & 2.6 & 7.1 & 1.1 & 0.5 & 2.21 \\
\hline \multirow{2}{*}{ Bitki } & $\mathrm{f}$ & 16 & 4 & 6 & 2 & 4 & 32 \\
\hline & $\%$ & 12.7 & 2.6 & 4.3 & 0,5 & 1,0 & 2.72 \\
\hline
\end{tabular}




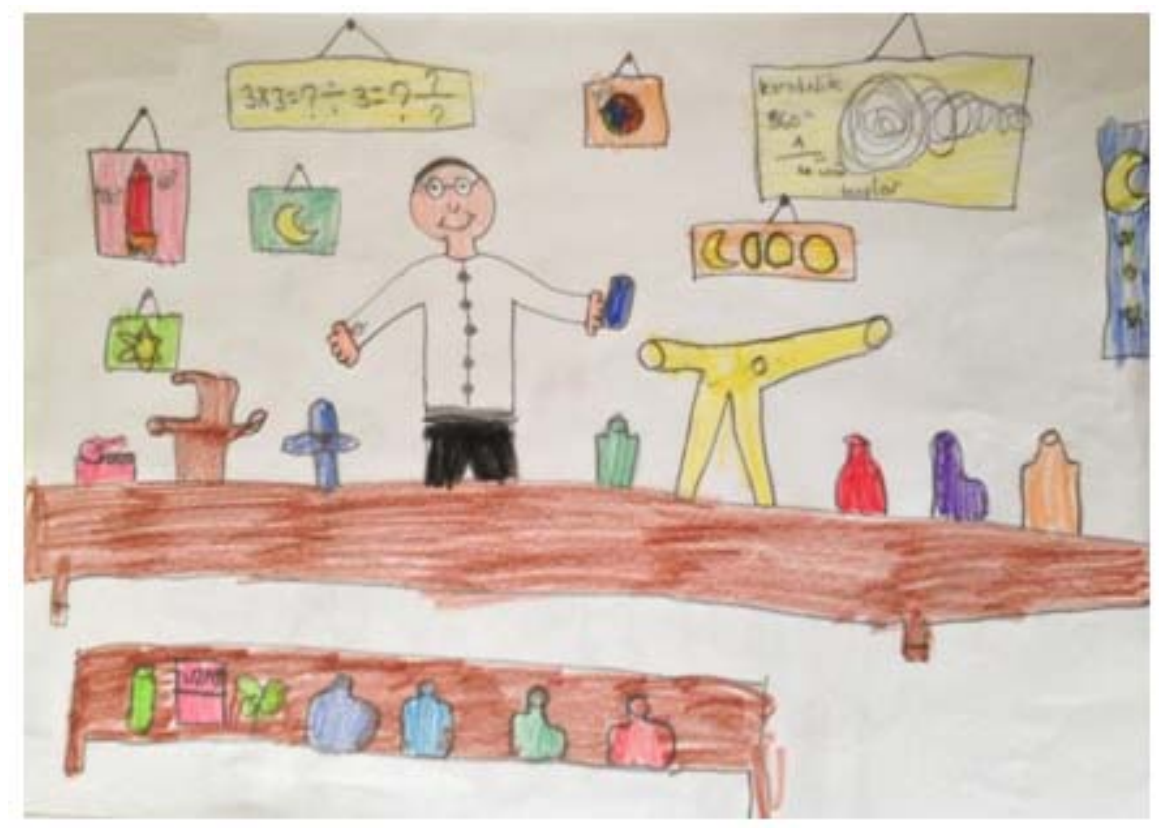

Şekil 4. Bilim İnsanının Kullandığı Bilimsel Araçlar ve Semboller

Ícatlar

Öğrencilerin çizimlerinde bilim insanının icat yaptığı, bu icatlarla çeşitli sorunlara çözüm bulduğu vurgulanmıştır. Ampul $(f=84, \% 7.15)$ ve robot $(f=36, \% 3.06)$ öğrencilerin çizimlerinde en çok yer alan icatlardandır. Bunların yanı sıra yüzen ev, kapı alarmı, bomba, telefon, zaman makinesi, bisiklet ve uçak, resimlerde vurgulanan diğer icatlar arasında yer almaktadır. Bu başlık altında elde edilen bir diğer sonuçta öğrencilerin resimlerinde iksir çizmesidir. Çalışmaya katılan öğrencilerin \%1.36'sı çizimlerinde kazan ve bilim insanının elinde sihir yaptığını vurgulayan çubuk çizmişlerdir. Bu çizimlerde öğrenciler bu kazan ve elindeki çubukla yapılan işin büyü olduğunu vurgulamışlar, resimlere iksir yazmışlardır. Bu resimlerle öğrencilerin bilim insanını büyü yapan bir kişi olarak gördükleri düşünülebilir. $\mathrm{Bu}$ resimlerin yanı sıra çeşitli semboller ve gösterimlerle bilim insanının icat yaptığı da 90 öğrenci tarafından ayrıca vurgulanmıştır. Bilim insanı çizimlerinde elde edilen icatların sınıflara göre frekans ve yüzde dağılımı Tablo 6'da, icatların çizildiği resimlere örnekler de Şekil 5 'te gösterilmiştir. 
Tablo 6. Bilim insanı çizimlerinde elde edilen icatların sınıflara göre dağılımı

\begin{tabular}{|c|c|c|c|c|c|c|c|}
\hline & & 1. sinif & 2. sinif & 3. sinif & 4. sinif & 5. sinif & Toplam \\
\hline \multirow{2}{*}{ Robot } & $\mathrm{f}$ & 0 & 0 & 0 & 28 & 8 & 36 \\
\hline & $\%$ & 0 & 0 & 0 & 3.7 & 2.1 & 3.06 \\
\hline \multirow{2}{*}{ Ampul } & $\mathrm{f}$ & 0 & 4 & 4 & 44 & 32 & 84 \\
\hline & $\%$ & 0 & 2.6 & 2.9 & 5.8 & 8.2 & 7.15 \\
\hline \multirow{2}{*}{ Yüzen ev } & $\mathrm{f}$ & 0 & 0 & 0 & 2 & 0 & 2 \\
\hline & $\%$ & 0 & 0 & 0 & 0.3 & 0 & 0.17 \\
\hline \multirow{2}{*}{ Kap1 alarmı } & $\mathrm{f}$ & 0 & 0 & 0 & 2 & 0 & 2 \\
\hline & $\%$ & 0 & 0 & 0 & 0.3 & 0 & 0.17 \\
\hline \multirow{2}{*}{ Süper kalem } & $\mathrm{f}$ & 0 & 0 & 0 & 2 & 0 & 2 \\
\hline & $\%$ & 0 & 0 & 0 & 0.3 & 0 & 0.17 \\
\hline \multirow{2}{*}{ İksir } & $\mathrm{f}$ & 0 & 4 & 0 & 6 & 6 & 16 \\
\hline & $\%$ & 0 & 2.6 & 0 & 0.8 & 1.5 & 1.36 \\
\hline \multirow{2}{*}{ Zaman makinesi } & $\mathrm{f}$ & 0 & 0 & 0 & 6 & 4 & 20 \\
\hline & $\%$ & 0 & 0 & 0 & 0.8 & 1.0 & 1.70 \\
\hline \multirow{2}{*}{ Bisiklet } & $\mathrm{f}$ & 0 & 0 & 0 & 2 & 0 & 2 \\
\hline & $\%$ & 0 & 0 & 0 & 0.3 & 0 & 0.17 \\
\hline \multirow{2}{*}{ Telefon } & $\mathrm{f}$ & 0 & 0 & 0 & 4 & 4 & 8 \\
\hline & $\%$ & 0 & 0 & 0 & 0.5 & 1.0 & 0.68 \\
\hline \multirow{2}{*}{ Bomba } & f & 0 & 0 & 0 & 6 & 6 & 12 \\
\hline & $\%$ & 0 & 0 & 0 & 0.8 & 1.5 & 1.02 \\
\hline \multirow{2}{*}{ Uçak } & $\mathrm{f}$ & 0 & 0 & 0 & 2 & 2 & 4 \\
\hline & $\%$ & 0 & 0 & 0 & 0.3 & 0.5 & 0.34 \\
\hline \multirow{2}{*}{ İcat } & $\mathrm{f}$ & 26 & 28 & 0 & 18 & 18 & 90 \\
\hline & $\%$ & 20.6 & 18.4 & 0 & 2.4 & 4.6 & 7.66 \\
\hline
\end{tabular}




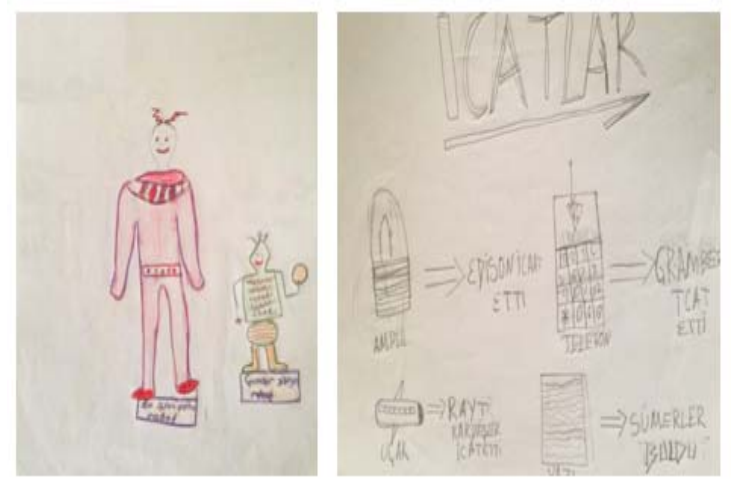

Şekil 5. Öğrencilerin çizimlerinde yer verdiği icatlardan örnekler

\section{Ünlü Bilim Insanlarl}

Ünlü bilim insanları, öğrencilerin bilim insanı çizimlerinde diğer bir öğe olarak karşımıza çıkmaktadır. Çalışmaya katılan öğrencilerin \%7.5'i Einstein'ı, \%8.0’1 Edison'u, \%2.55'i Newton'u resmetmişlerdir. Bu bilim adamlarının yanı sıra çizimlerin \%0.85'inde Galilei'ye, \%0.85'inde Mendel'e, \%0.34'ünde Wright kardeşlere, \%0.34'ünde Ian Crouse'e rastlanmıştır. Bu bilim insanlarının yanı sıra dört öğrencinin çiziminde Mevlana yer almıştır. Çalışmadan elde edilen bir diğer sonuçta ünlü bilim insanı çizimlerinin üçüncü sınıftan itibaren yer alıyor olmasıdır. Bilim insanı çizimlerinde yer verilen ünlü bilim insanlarının sınıflara göre frekans ve yüzde olarak dağılımı Tablo 5'te örnek çizimler ise Şekil 6'da verilmiştir.

Tablo 5. Bilim insanı çizimlerinde yer verilen ünlü bilim insanlarının sınıflara göre dağılımı

\begin{tabular}{|c|c|c|c|c|c|c|c|}
\hline & & 1. sinif & 2. sinif & 3. sinif & 4. $\sin 1 f$ & 5. sinif & Toplam \\
\hline \multirow{2}{*}{ Albert Einstein } & $\mathrm{f}$ & 0 & 0 & 0 & 56 & 32 & 88 \\
\hline & $\%$ & 0 & 0 & 0 & 7.4 & 8.2 & 7.5 \\
\hline \multirow{2}{*}{ Thomas Edison } & $\mathrm{f}$ & 0 & 0 & 10 & 52 & 32 & 94 \\
\hline & $\%$ & 0 & 0 & 7.1 & 6.9 & 8.2 & 8.0 \\
\hline \multirow{2}{*}{ Graham Bell } & $\mathrm{f}$ & 0 & 0 & 0 & 8 & 0 & 8 \\
\hline & $\%$ & 0 & 0 & 0 & 0.8 & 0 & 0.68 \\
\hline \multirow{2}{*}{ Isaac Newton } & $f$ & 0 & 0 & 0 & 16 & 14 & 30 \\
\hline & $\%$ & 0 & 0 & 0 & 2.1 & 3.6 & 2.55 \\
\hline Ian Crouse & $\mathrm{f}$ & 0 & 0 & 0 & 4 & 0 & 4 \\
\hline
\end{tabular}




\begin{tabular}{|c|c|c|c|c|c|c|c|}
\hline & $\%$ & 0 & 0 & 0 & 0.5 & 0 & 0.34 \\
\hline \multirow{2}{*}{ Galileo Galilei } & $\mathrm{f}$ & 0 & 0 & 0 & 6 & 4 & 10 \\
\hline & $\%$ & 0 & 0 & 0 & 0.8 & 1.0 & 0.85 \\
\hline \multirow{2}{*}{ İbni Sina } & $\mathrm{f}$ & 0 & 0 & 0 & 2 & 0 & 2 \\
\hline & $\%$ & 0 & 0 & 0 & 0.3 & 0 & 0.17 \\
\hline \multirow{2}{*}{ Gregor Mendel } & $\mathrm{f}$ & 0 & 0 & 0 & 10 & 0 & 10 \\
\hline & $\%$ & 0 & 0 & 0 & 1.3 & 0 & 0.85 \\
\hline \multirow{2}{*}{ Wright Kardeşler } & $\mathrm{f}$ & 0 & 0 & 0 & 2 & 2 & 4 \\
\hline & $\%$ & 0 & 0 & 0 & 0.3 & 0.5 & 0.34 \\
\hline
\end{tabular}
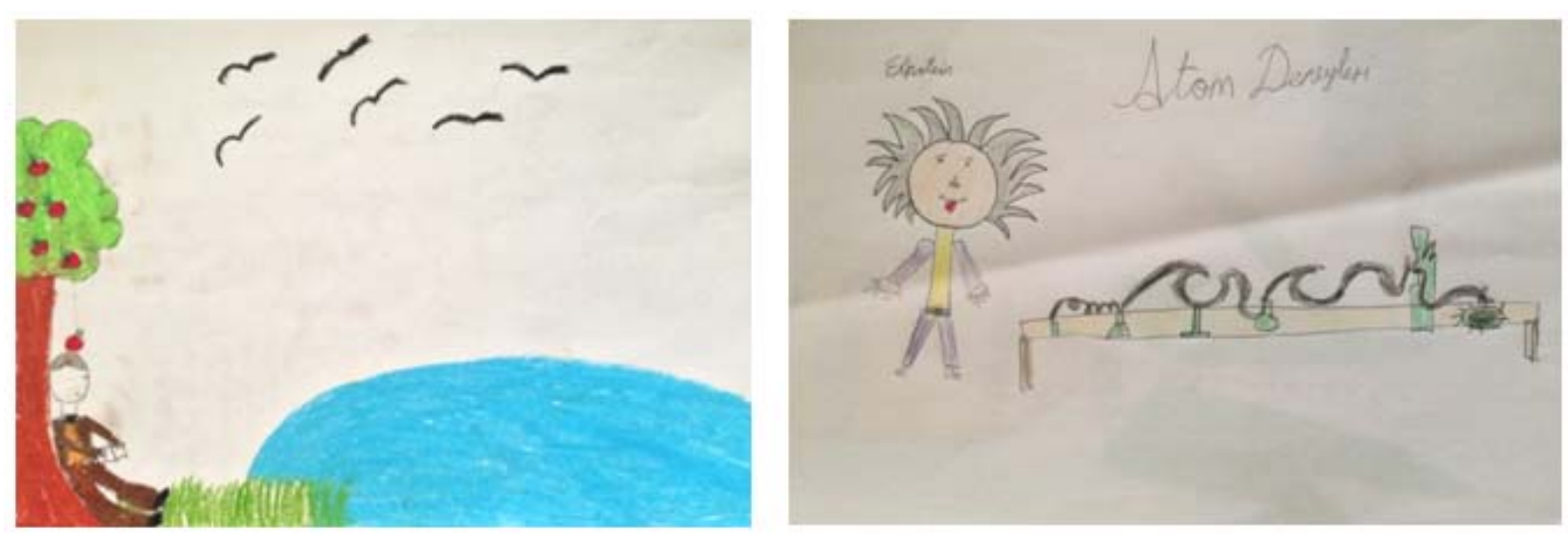

Şekil 6. Ünlü Bilim İnsanı Çizimlerine Örnekler (solda Newton, sağda Einstein)

\section{Tartışma, Sonuç ve Öneriler}

Bilim ele aldığg konular ve kullandığı yöntem açısından düşünüldüğünde çok yönlü, sınırları belli olmayan, karmaşı bir yapıya sahiptir. Bilim, insanın her alandaki bilgisini arttırmayı, evrende meydana gelen olayları açıklamayı, gelecekte meydana gelecek olaylar hakkında öngörülerde bulunmayı amaçlar. Bilimde meydana gelen gelişmeler ile mühendislikte, tıpta, ekonomide, tarımda ve diğer alanlarda karşılaşılan problemleri çözmek mümkün olur. Bilim insanı, bilgiyi elde etme sürecinde bilimsel yönteme bağlı kalarak, düşünsel ve eylemsel işlemleri sürdüren kimsedir. Bilim; merak etmeyi, olaylara şüpheci yaklaşmayı, eleştirel ve mantıksal düşünmeyi temel alan bir çalışma olarak düşünülürse, bilim insanı da bu çalışmayı yapan kişidir. Bilim insanının, bilimsel bilgiyi elde etme sürecinde meraklı olması ve bilgi edinme yolunda bilimsel yöntem dışındaki diğer tutumları kuşku ile karşılaması gerekir (Armağan, 1974). Bilim insanı kuşkucudur. Kendi elde ettiği sonuçlar da 
dâhil olmak üzere verilerin tamamına kuşku ile bakar. Bilim insanı elde ettiği sonuçları saptırmaz, yanlış bilgiler sunmaz, çalışmasını doğru olmayan bilgiler üzerine kurmaz. Araştırmanın başından sonuna kadar tüm süreçte nesnel, tarafsız ve dürüst davranır. Bilim insanları, çalışması sırasında elde ettiği verileri ve çalışmasının sonuçlarını paylaşmalıdır. $\mathrm{Bu}$ sonuçları diğer bilim insanlarının ulaşımına açmalı, gelecek eleştirilere ve yeni fikirlere açık olmalıdır. Bilim insanının sahip olduğu bu özellikler, bilimin ilerlemesine de katkıda bulunur. Yalnızca bilim insanının değil sokaktaki bireyin de amacı, çevresinde meydana gelen olaylara anlam vermek, bunları tanımlamaya çalışmak ve ileriye yönelik isabetli tahminlerde bulunmak, bunun sonucunda da kontrol yetisine sahip olmaktır.

Ülkelerin gelişen dünyaya ayak uydurabilmeleri için, bilgiye ulaşma yollarını bilen, ulaştığı bilgiyi analiz eden, bilim ve teknolojideki gelişmeleri takip ederek günlük yaşantısına uyarlayabilen, bilimsel düşünme yetisine sahip bireyler yetiştirmeleri gerekmektedir. Bireylerin istendik özelliklere sahip olabilmeleri için temelde bilimin ve bilimin doğasını anlamaları, bununla birlikte bilime ve bilimle ilgilenen insanlara karşı doğru ve pozitif bir anlayışa sahip olmaları gerekmektedir. Çocuklar formal eğitim öncesinde ve sırasında, okul içinde ya da okul dışında, deneyimleri ve yaşantıları ile kendi bilim ve bilim insanı imajlarını oluşturmaktadırlar. Çocukların bilimi öğrenme ve bilimle ilgilenmeye yönelik tavırlarını etkileme açısından, benimsedikleri bilim insanı modeli çok önemlidir. Üstelik bu model gelecekte bilimsel çalışmalara devam edip edemeyeceklerine etki edebilir. Ayrıca, ilgili alanyazın öğrencilerin bilim insanı hakkında klişeleşmiş fikirlerinin olduğunu söylese de değişen programlarla birlikte, öğrencilerin bilim insanı ve bilimsel çalışma hakkında farklı görüşlerinin olması beklenmektedir. Bu noktadan hareketle, ilköğretim öğrencilerinin bilim insanı hakkındaki görüşlerinin saptanması önem kazanmaktadır, araştırılması gereken bir konudur. Yapılacak olan çalışmalar, bir yandan öğretim programlarının amacına ulaşıp ulaşmadığı konusunda da bize fikir verecektir.

Farklı sınıf düzeylerinde eğitim görmekte olan öğrencilerin bilime ve bilim insanına bakışı son 80 yılda birçok araştırmaya konu olmuştur. Dünyanın farklı kültürlerinde ve farklı toplumlarında yapılan araştırmalarda öğrencilerin bilim insanını beyaz önlük giyen, saçları beyazlamış, dökülmüş ya da dağınık, gözlüklü, orta yaşlı genellikle erkek olarak tanımladıkları ortaya çıkmaktadır (Barman, 1996-1997- 1999; Bodzin, \& Gehringer, 2001; Chambers 1983; Finson, 2002-2003; Finson, Pedersen, \& Thomas, 2006; Flick, 1990; Fort \& Varney 1989; Finson, Beaver, \& Cramond 1995; Fung, 2002; Huber \& Burton 1995; Moseley, \& Norris, 1999; Odell, Hewitt, Bowman, \& Boone, 1993; Pedersen, \& Thomas, 1999; Rosenthal, 1993; Ryder, Leach, \& Driver, 1999; Schibeci \& Sorensen, 1983; Song, \& 
Kim, 1999; Symington, \& Spurling, 1990; Thomas, Pedersen, \& Finson, 2001).Yine bu araştırmalarda bilim insanının çalışma ortamı laboratuar olarak tanımlanmakta, çalışma ortamında deney malzemelerinin ve teknolojik aletlerin yer aldığı vurgulanmaktadır. $\mathrm{Bu}$ çalışmadan elde edilen sonuçlar da alanyazındaki diğer araştırmaların bulgularıyla benzerlik göstermektedir (Mead \& Meatrux, 1957; Chambers, 1983; Fort \& Varney, 1989; Newton \& Newton, 1992; Finson, Beaver \& Crammond, 1995; Korkmaz, 2004; Buldu, 2006; Türkmen, 2008). Çalışmada özellikle gözlüklü (\%19.9), önlüklü (\%16.5) ve dağınık saçlı (\%11.9) bilim insanı çizimlerine vurgu yapılmıştır. Çalışmaya katılan öğrencilerin yarısı (\%50.9’u) bilim insanlarını laboratuarda çalışırken göstermişlerdir. Öğrencilerin sadece \%2.72'si bilim insanını doğada, yine sadece \%2.1', ise uzayda göstermişlerdir. Öğrenciler bu çizimleriyle bilimsel çalışmaların ancak laboratuar gibi iç mekânlarda yürütülebileceğini düşünmektedir. Bunun temel nedeni ders kitapları ve medyada bilim insanlarının laboratuar ortamında gösterilmesinden kaynaklanabilir.

Alanyazınla bir diğer benzerlik gösteren sonuç bilim insanının cinsiyeti konusunda elde edilmiştir. Çalışmaya katılan öğrencilerin \%65.6'sı bilim insanını erkek olarak çizerken \%22.5'i ise kadın olarak resmetmiştir. Öğrencilerin sadece \%0.9'u kadın ve erkek bilim insanını bir arada çalışırken çizmişlerdir. Elde edilen sonuçlar ile daha önceden yapılan araştırmalar karşılaştırıldığında öğrencilerin bilim insanının cinsiyeti ile ilgili yerleşmiş bir yargıya sahip olduğu söylenebilir. Nuhoğlu ve Afacan'ın (2007) yaptığı araştırmada uygulamaya dâhil olan öğrencilerin \%60'ı bilim insanını erkek, \%23'ü ise bayan olarak, Ekici, Doğan ve Kaya'nın (2006) araştırmasında öğrencilerin \%71'inin bilim insanını erkek, \%36'sının ise kadın olarak çizdiği görülmektedir. Araştırmadan elde edilen bir diğer sonuç ise kadın bilim insanı çizen öğrencilerin büyük bir çoğunluğunun kız çocuğu olmasıdır Gounsoulin'in (2001) ve Buldu'nun (2006) elde ettiği sonuçlarla benzerlikler göstermektedir. Eldeki verilerle elde edilen sonucu yorumlamak çok mümkün gözükmese de sonuçlar çocukların çizdikleri bir resimde genellikle kendi cinsiyetlerinden bir insan figürüne yer verdiklerini düşündürtmektedir.

2005 yılında fen ve teknoloji dersi programının yayınlanması ve uygulanmaya başlanması ile birlikte bilime ve bilim insanına bakışta değişiklikler olması beklenmektedir. Yenilenen bu programlarla birlikte, fen ve teknoloji dersleri ile öğrencilerin dünyaya bir bilim insanının bakış açısı ile bakabilmesi, yakın çevresinde karşılaştıkları problemleri bir bilim insanı edasıyla çözebilmesi amaçlanmakta, bilimsel süreç becerilerinin kazandırılmasına bu maksatla daha fazla önem verilmektedir. Öğrencilerin, bilim insanı imajlarında alanyazında 
yapılan diğer çalışmalara göre farklılıklar olmaması, sekiz yıldır uygulamada olan programın amaçlarına ne derece ulaştığı konusunda soru işaretleri yaratmaktadır. Programda yer almasına rağmen bazı temel düşüncelerin öğrencilere kazandırılamamış olması, programın sınıflarda planlandığı gibi uygulanmadığı izlenimini yaratmaktadır.

Okulda verilen eğitim, ders kitapları, öğretmen davranışları, öğretmenin cinsiyeti ve kişiliği, televizyon, bilim kurgu kitapları, çizgi filmler özellikle küçük yaştaki öğrencilerin bilim insanı imajını oluşturmada etkili faktörler olarak karşımıza çıkmaktadır (Buldu, 2006; Türkmen, 2008). İlgili araştırmalar, ders kitaplarının okullarda kullanılan birincil kaynak olduğunu, öğretmenlerin de ders süresinin önemli bir kısmını ders kitabını kullanarak geçirdiklerini göstermektedir. Bu nedenle, ders kitaplarında bilim ve bilim insanı üzerine olumlu imaj oluşturmaya yardımcı olacak içeriğe yer verilmesi (She, 1995; Sjoberg, 1993), bilim insanlarının sahip oldukları özelliklerin vurgulanması, öğrencilerin zihinlerinde oluşturdukları bilim ve bilim insanı imajının şekillenmesinde etkili olacaktır (Türkmen, 2008). Yine kitaplarda ve derslerde öğrencilerin düzeyine uygun olacak şekilde bilim tarihinden bahsedilmesi, bilim insanlarının yaşantılarından örnekler verilmesi yerinde olacaktır.

Çocuklar, kavramlar hakkındaki algılarını yaşantıları ve bu yaşantıları sırasında edindikleri deneyimlerle şekillendirirler. Bu durum 'bilim' ve ‘bilim insanı' kavramları için de geçerlidir. Eğer çocukların yaşantıları çeşitlendirilmez ve elde ettikleri bilgi birikimleri televizyon, Internet, ders kitabı, öğretmen gibi birkaç kaynak ile sınırlandırılırsa çocukların bu konulardaki algılarının yeterli ve doğru olması beklenemez. Yaşantıları çeşitlendirmek için çocukları bilim insanları ile tanıştırmak, onlarla aynı ortamı paylaşmalarını sağlamak etkili bir yöntem olacaktır. Bunun için üniversitelere ve çeşitli bilimsel araştırma yapma amaciyla kurulan kurum ve kuruluşlara yapılacak geziler ya da bu kurumlardan davet edilecek bilim insanları çocukların vizyonunu değiştirmeleri, bilim insanı hakkındaki algılarını şekillendirebilecek yaşantılar oluşturabilmeleri için gereklidir. Bu durum Flick'in 1990 yılında beşinci sınıf öğrencileri ile doktora öğrencilerini bir araya getiren çalışmasında da net bir şekilde ifade edilmiştir. Kırkyedi öğrenci, dört doktora öğrencisi ile üç hafta boyunca devam eden çalışmada çalışma öncesi ve sonrasında öğrencilere bilim insanı çizimleri yaptırılmıştır. Çalışma öncesi çizimlerinde laboratuarda ekipmanlarla çalışan, laboratuar önlüklü, erkek, bilim insanı çizimleri elde edilirken, çalışma sonrası çizimlerinde bitki ve hayvanlarla çalışan, kadın bilim insanı yer almıştır. Sınıf dışı etkinlikler, müzelere, bilim merkezlerine yapılacak geziler, doğada yapılacak gözlemler, incelemeler ve araştırmalar 
çocukların bilim dolayısıyla bilim insanına yönelik algılarını şekillendirecek farklı yaşantılar sunacaktır. Bu tür etkinliklerin dönem içerisinde yapılması önerilmektedir.

İlkokul çağındaki öğrenciler her konuda öğretmenlerini örnek almaktadır. Çocukların kavramları zihinlerinde doğru yapılandırması ilkokul öğretmenlerinin sahip olduğu bilgi birikimi ve öğrencilerine sağlayacakları deneyimlerle ilişkilidir. Bir öğretmen uzmanlık alanı ne olursa olsun öğrencilerini karsılaştıkları problemleri çözebilen, eleştirel düşünebilen, çevresine karsı sorumluluklarını bilen ve buna göre hareket eden, çevresinde olup biten olaylara karsı meraklı ve duyarlı, bilgiyi üreten ve bilgiyi kullanabilen, bilimsel bilgiyi anlayan, bilimsel çalışmaları yürütebilen, bilimsel tartışmalara katılabilen, bilimin toplumu nasıl etkilediğini ve ondan nasıl etkilendiğini anlayan bireyler olarak yetiştirmekle sorumludur. $\mathrm{Bu}$ sorumluluklarını yerine getirebilmeleri için öğretmenlerin sınıflarında bilimsel bilginin önemini vurgulamaları, bilimin doğasını öğrencilerine doğru bir şekilde aktarmaları gerekmektedir. Öğretmenler, bilim ve bilim insanı konularında bilgi aktarımında bulunurken cinsiyet vurgulayan bir dilden kaçınmalı, bilimin doğası ve bilimsel bilginin öğrencilere nasıl aktarılması gerektiği konusunda bir bilgi birikimine sahip olmalı, bu konularda yanlış inançlara sahip olmamaları gerekmektedir. Eğer bir öğretmen bilimin erkekler tarafından sadece laboratuar ortamında yapılabileceğine inanıyorsa bu öğretmenin yetiştireceği öğrencilerin bilim insanı hakkındaki algılarının yanlış, eksik ya da sınırlı olması kaçınılmazdır.

Resimler, çocukların belirli bir konudaki duygularını, düşüncelerini ve algılarını belirlemek için geçerli ve güvenilir ölçme araçları olarak karşımıza çıkmaktadır. Ancak, her ölçeğin olduğu gibi resimlerin de bilimsel araştırmalarda kullanılmasında bazı sınırlılıkları bulunmaktadır. Örneğin yaş düzeyi azaldıkça çocukların çizdikleri imajları net bir şekilde tanımlamak zorlaşmaktadır. Ya da bu çalışmada olduğu gibi neden sadece kız öğrencilerin bayan bilim insanı çizdiklerini, ya da çocukların resimlerinde neden kazan gibi imgelere yer verdiklerini sadece çizimler kullanarak belirlemek mümkün değildir. 'Bir Bilim İnsanı Çiz Testi' her ne kadar 1980'li yıllardan beri kullanılan bir ölçek olsa da bu sınırlılıkların en aza indirilebilmesi için resim analizlerinden elde edilen verilerin diğer başka ölçme araçları ile de desteklenmesi önerilmektedir.

$\mathrm{Bu}$ araştırmada yer alan çalışma grubu her ne kadar sayıca sınırlı olsa ve tüm evreni temsil yeteneği sınırlı olsa da bu yaş grubundaki öğrencilerin bilim insanına bakışlarından bir kesit sunduğu için elde edilen bulgular değerlidir. Benzer çalışmaların farklı çalışma gruplarıyla tekrarlanması, belirli bir çalışma grubundan elde edilen bulguların yıllara göre de 
sınıf düzeyi arttıkça değişip değişmediğinin gözlenmesi gerekmektedir. Çeşitli yaş düzeyindeki öğrencilerin bilim insanı algıları üzerine bu güne kadar birçok çalışma yapılmıştır. $\mathrm{Bu}$ alandaki bilgi birikimi oldukça fazladır. Alanda yapılmış olan tüm çalışmalardaki verileri derleyip analiz edecek metaanaliz çalışmalarının da yapılmasına ihtiyaç duyulmaktadır.

\section{Kaynakça}

Armağan, İ. (1974). Bilgi ve Toplum:Bilgi Sosyolojisine Giriş. İstanbul: Otağ Yayınları.

Barman, C. R. (1996). How do students really view science and scientist? Science and Childtren,34(1) 30-33.

Barman, C. R. (1997). Student views of scientists and science: Results from a national study. Science and Children, 18-23.

Barman, C. R. (1999). Completing the study: High school students' views of scientists and science. Science and Children, 16-21.

Beardslee, D. C. \& O'Dowd, D. D. (1961). The college-student image of the scientist, Science, 133, 997-1001.

Bodzin, A. \& Gehringer, M. (2001). Can meeting actual scientists change students' perceptions of scientists? Science and Children, 39(1), 36-41.

Buldu, M. (2006). Young children's perceptions of scientists: A preliminary study. Educational Research, 48(1), 121-132.

Chambers, D. W. (1983). Stereotypic images of the scientist: The Draw-A-Scientist Test. Science Education, 67, 255-265.

Ekici, F., Doğan, A., \& Kaya, O. N. (2006) “İlköğretim İkinci Kademe (6., 7., 8. Sınıf) Öğrencilerinin Bilim İnsanı İmajları,” VII. Ulusal Fen Bilimleri ve Matematik Eğitimi Kongresi. Gazi Üniversitesi Gazi Eğitim Fakültesi, Ankara, TÜRKIYYE.

Finson, K. D. (2003). Applicability of the DAST-C to the images of scientists drawn by students of different racial groups. Journal of Elementary Science Education, 15(1), 15 26.

Finson, K. D. (2002). Drawing a scientist: What we do and do not know after fifty years of drawings. School Science and Mathematics, 102, 335-346.

Finson, K. D., Beaver, J. B. \& Crammond, R. L. (1995). Development of a field-test checklist for the draw a scientist test. School Science and Mathematics, 95(4), 195-205.

Finson, K. D., Pedersen, J. \& Thomas, J. (2006). Comparing science teaching styles to students' perceptions of scientists. School Science and Mathematics, 106 (1), 8-15. 
Flick, L. (1990). Scientist in residence program improving children's image of science and scientists. School Science and Mathematics, 90,205-214.

Fort, D. C. \& Varney, H. L. (1989). How students see scientists: Mostly male, mostly white, and mostly benevolent. Science and Children, 26, 8-13.

Fung, Y. H. (2002). A comparative study of primary and secondary school students' images of scientists. Research in Science \& Technological Education, 20 (2), 199-213.

Garner, P. L. (1975). Attitudes to science: A review, Studies in Science Education, 2, 1-41.

Gonsoulin, W. B. (2001). How Do Middle School Students Depict Science and Scientist.

Mississippi State University, Curriculum and Instruction, Doctoral Thesis, UMI Number: 3005589.

Güler, T. \& Akman B. (2006). 6 Yaş çocuklarının bilim ve bilim insanı hakkındaki görüşleri, Hacettepe Üniversitesi Eğitim Fakültesi Dergisi, 31- 55-66.

Hammrich, P. (1997). Yes, daughter you can: Empowering parents is the first step toward improving females' achievement in science. Science and Children, 34(4), 21-24.

Huber, R. A. \& Burton, C. M. (1995). What the students think scientists look like? School Science and Mathematics, 95, 371-376.

Kaya, O. N., Doğan, A. \& Öcal, E. (2008). Turkish elementary school students' images of scientists. Eurasian Journal of Educational Research, 8(32), 83-100.

Knight, M. \& Cunningham, C. (2004). Draw an engineer test (DAET): Development of a tool to investigate students' ideas about engineers and engineering. Paper presented at the American Society for Engineering Education Annual Conference \& Exposition.

Korkmaz, H. (2004). The Images of the Scientist through the Eyes of the Turkish Children. Panhandle Science \& Mathematics Conference, Canyon, Texas, USA.

Krajkovich, J. G. (1978). The development of a science attitude instrument and an examination of the relationships among science attitude, field dependenceindependence and science achievement. Doctoral Dissertation, Rutgers University.

Mead, M. \& Metreaux, R. (1957). The Image of Science Among High School Students. Science, 126, 384-390.

Medina-Jerez, W., Kyndra, V. M. \& Orihuela-Rabaza, W. (2011). Using the DAST-C to explore Colombian and Bolivian students' images of scientists. International Journal of Science and Mathematics Education, 9(3), 657-690.

Moseley, C. \& Norris, D. (1999). Pre-service teahcers' views of scientists. Science and Children, 37, 50-53. 
Newton, D. P. \& Newton, L. D. (1992). Young children's perceptions of science and the scientist. International Journal of Science Education, 14(3), 331-348.

Nuhoğlu, H. \& Afacan, Ö. (2007). İlköğretim Öğrencilerinin Bilim İnsanına Yönelik Düşüncelerinin Değerlendirilmesi. 16. Ulusal Eğitim Bilimleri Kongresi, 05-07 Eylül 2007, Tokat

Odell, M.R.I., Hewitt, P., Bowman, J. \& Boone, W.J., (1993). Stereotypical images of scientists: A cross-age study. Paper presented at the 41st annyal national meeting of the National Science Teachers Association, Kansas City, MO.

Özsoy, S. (2012). Is the earth flat or round? Primary school children's understandings of the planet earth: The case of turkish children. International Electronic Journal of Elementary Education, 4 (2), 407-415.

Özsoy, S. (2012a). İlköğretim öğrencilerinin çevre algılarının çizdikleri resimler aracılığıyla incelenmesi. Kuram ve Uygulamada Eğitim Bilimleri, 12 (2), 1117-1139.

Pedersen, J. E. \& Thomas, J. (1999). Draw-A-Science-Teacher Checklist: Children's Perceptions of Teaching Science. Paper presented at the National Association of Researchers in Science Teaching International Meeting, Boston, MA.

Picker, S. \& Berry, J. S. (2000). Investigating pupils' images of mathematicians. Educational Studies in Mathematics, 43, 65-94.

Renow, S. (2003). The draw an archaeologist test: A good way to get the ball rolling. Science Activities, 40(3), 31-36.

Rodriguez, S. G. (1975). Mexican adolescents' image of the scientist, Social Studies In Science, 5, 355-361.

Rosenthal, D. B. (1993). Images of scientists: A comparison of biology and liberal studies majors. School Science and Mathematics, 83(1), 14-20.

Ryder, J., Leach, J. \& Driver, R. (1999). Undergraduate science students' images of science. Journal of Research in Science Teaching, 36(2), 201-219.

Schibeci, R. (2006). Students image of scientists: What are they? Do they matter? Teaching Science, 52(2), 12-16.

Schibeci, R. A. (1986). Image of science and scientists and science education. Science Education. 70(2), 139-149.

Schibeci, R. A. \& Sorensen I. (1983). Elementary school children's perceptions of scientists. School Science and Mathematics, 83(1), 14-20. 
She, H. (1995). Elementary and middle school students' image of science and scientists related to current science textbooks in Taiwan. Jouırnal of science education and technology. 4, 283-294.

Sjoberg, S. (1993). Gender equality in science classrooms. In Fraser, J. B. (ed.), Research Implications for Science and Mathematics Teachers, Vol.1. Curtin University of Technology, Perth, Western Australia.

Song, J. \& Kim, K. (1999). How Korean students see scientists: The images of the scientist. International Journal of Science Education, 21, 957-977.

Symington, D. \& Spurling, H. (1990). The draw-a-scientist test: Interpreting the data. Research in Science and Technological Education, 8(1), 75-77.

Thomas, J. A., Pedersen, J. E. \& Finson, K. D. (2001). Validating the Draw-A ScienceTeacher-Test checklist: Exploring mental models and teacher beliefs. Journal of Science Teacher Education, 12(3), 295-310.

Türkmen, H. (2008). Turkish primary students' perceptions about scientist and what factors affecting the image of the scientist. Eurasia Journal of Mathematics, Science and Technology Education,4(1), 55-61.

Villanen, H. \& Jonsson, G. (2013). Envisioning the future - A question of distances. International Electronic Journal of Environmental Education, 3(1), 1-16. 